has not yet been ascertained. It was flrst noted in 1897 in New Guinea, but it has been observed also in Siam, Java, Madagascar, in both French and British Guinea, and in Algeria. Drs. Castellani and Tejera describe a skin disease of which we have not previously heard. It occurs in Fenezuela, where it is called "cute" and is said to be fairly common. Bright yellow patches with little or no desquamation appear, sometimes in childhood, and very slowly spread. It is thought to be identical with an infection described by Çastellani in Ceylon under the name of tinea flava. Spores were observed in scrapings from the yellow patches, but no lungus growth could be obtained from them.

AT the meeting of the Society for the Study of Inebriety to be held at 11, Chandos Street, W.1, on Tuesday, July 10th, at 4 p.m., Professor A. Louise McIlroy will open a discussion on the influence of alcohol and alcoholism upon ante-natal and infant life.

A MEMORIAL to the late Dr. Murdoch Mackenzie was unveiled on June 22nd in the Isle of Lewis Hospital, of which institution he was one of the founders and for twenty.six years its medical superintendent and devoted friend.

THE very fine collection of Hispano-Moresque pottery made by Mr. Francis W. Mark is to be sold at Christie's on July 10th. It contains some rare pharmacy jars of the fleteenth century. Part of the collection was exhibited last summer at the Royal Society of Medicine's social evening.

THE University of London Press announces for early publication an illustrated volume on The Diseases of the Breast, by Willmott H. Evans, M.D., F.R.C.S., surgeon to the Royal Free Hospital.

A SECOND (revised and enlarged) edition of Choyce's System of Surgery, in three volumes, is announced for early publication by Messrs. Cassell.

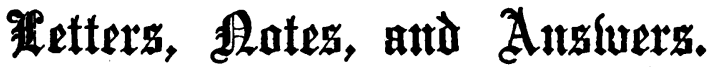

ORIGINAL ARTICLES and LETTERS forwarded for publication are understood to be offered to the British Medical JouRAal alone unless the contrary be stated.

Correspondents who wish notice to be taken of their communications should authenticate them with their names-of course not necessarily for publication.

4s, owing to printing difficulties, the JouRsal must be sent to press earlier than hitherto, it is essential that communications intended for the current issue should be received by the first post on isthy documents on Monday.

Authors desiring reprints of their articles published in the BritisH MEDical JourNal are requested to communicate with the Office, 429, Strand, W.C.2, on receipt of proof.

Is order to avoid delay, it is particularly requested that ALL letters on the editorial business of the JourNaL be addressed to the Editor at the Office of the Joursal.

The postal address of the British Medicas Association and British Medical Jovren is 429, Strand, London, W.C.2. The telegraphic addresses are :

1. EDITOR of the British MEdical Jourat, Aitiology, Westrand, London; telephone, 2630, Gerrard.

2. FINANCIAL SECRETARY AND BUSINESS MANAGER (Advertisements, etc.), Articulate, Westrand, London; telephone, 630 , Gerrard.

3. MEDICAL SECRETARY, Medisccra, Westrand, London; telephone, 2630, Gerrard. The address of the Irish Office of the British Medical Association is 16, South Frederick Street, Dublin (telegrams: Bacillus, Dublin; telephone, 4737, Dublin), and of the Scottish Office, 6, Rutland Square, Edinburg (telegrams : Associate, Edinburgh; telephone, 4361, Central).

\section{QUERIES AND ANSWERS}

"G. T." inquires if there is any hospital in the British Isles where a native of Sierra Leone, who is an M.A., B.Sc., and M.B., B.S , could obtain a house-surgeon's appointment. Failing such, could the graduate be attached as a pupil to learn the work of house-surgeon and at the same time obtain an insight into hospital administration?

\section{UNCERTIFIED MIDWIVES.}

"Oxon." writes: (1) Is a nurse who holds certificates of proficiency in midwifery, but has not passed the examination of the Central Midwives Board, eligible for registration as a midwife? (2) In the event of her being eligible, am I as a doctor permitted to allow her to conduct cases without my actually being present at the confinement?

${ }^{*}{ }^{*}$ (1) No woman (other than a registered medical practitioner) can act as a midwife in England or. Wales unless she holds the Board's certificate. This certiflcate she can now only obtain by passing the Board's examination or by being enrolled by virtue of holding the certificate of either the Central Midwives Board for Scotland or the Central Midwives Board for Ireland, obtained as a result of training and examination equivalent to the standard adopted by the Board. (2) If a medical practitioner were to allow an uncertifled woman to conduct cases without his actually being present at the confinements, the woman would be liable to be prosecuted and the doctor to be reported to the General Medical Council for "covering" an uncertified woman.

\section{INCOME TAX.}

"I. B. S." bought a practice as from May lst, 1921. There appears to be some difficulty in the way of an assessment on the three years' average of his predecessar; "L. B. S." has supplied an account of his cash recelpts and expenses to the inspector, who declines to take the receipts on that basis, and claims to add thereto the value of the debts outstanding at the end of the year. He also declines to allow a deduction for removal expenses The proper basis is of course the average of the three previou year's profts, and if those figures are not available, the profits of the current year are useful only so far as they may serve to indicate what that average probably amounted to, or, if the profits have fallen off, as a basis of adjustment to meet tha special case. The inspector's point about the necessity for taking bookings into account during the early years holds good ; though they have not in fact been received. The claim to deduction for removal expenses cannot be upheld as there judicial authority against it; the expense is not incurred so much in carrying on the practice as in acquiring it.

“H. E. G." replaced a 10-h.p. S. car by a 10-h.p. F. costing $£ 662$ the cost of a car of similar make and the same horse-power as th S. is estimated at $£ 600$. He has claimed to deduct $£ 600-£ 10$ allowed for the old car, net $£ 500$. The inspector of taxes says example, $£ 220$ (cost of old car), less $£ 100$ - that is, $£ 120$ only.

* * It is beyond dispute that a professional man is entitled to cost of replacement and not to depreciation-which in the long run would be of greater benefit. In the official evidence given before the Royal Commission on the Income Tax it was stated that the cost of replacement would be measured by the expense necessary to replace a machine, and that where that amount exceeded the original cost no restriction would be enforced, except that where the expenditure was incurred partly for improvement the portion so jncurred could not be allowed. Assaming that a 10-h.p. car of similar quality and type to the $S$ would cost $£ 600$ when the F. was bought, our correspondent is correct in claiming to deduct $£ 500$.

\section{LETTERS, NOTES, ETC.}

MESsRs. Boots of Nottingham have issued a list of chemicals of guaranteed purity for use in research. The majority of the substances in the list are manufactured by the firm.

\section{Correction}

DR. GORDON NorRIE of Copenhagen calls attention to an error in the annotation on the prevention of ophthalmia neonatorum in Denmark published in the JoURNAL of June 23rd. In the fourth line from the end (p. 1062) is a quotation which should read as follows: "it is impossible by prophylaxis to prevent the infection taking place after birth" -that is, in the days after the
birth.

\section{Pacancies.}

NOTIFICATIONS of offces vacant in universities, medical colleges, aud of vacant resident and other appointments at hospitals, will be found at pages 31,34 , and 35 of our advertisemen columns, and advertisements as to partnerships, assistantships, and locumitenencies at pages 32 and 33

A short summary of vacant posts notified in the advertisement columns appcers in the Supplement at page 12.

SCALE OE CHARGES FOR ADYERTIGEMENTS IN THE BRITISH MEDICAC JOURNAL

Six lines and under

Each additional line

... 10000

Whole single column (three columns to page) $\cdots$

$\begin{array}{llllllll}\text { Half single column } & \ldots & \ldots & \ldots & \ldots & 3 & 15 & 0\end{array}$

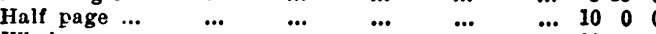

$\begin{array}{llll}20 & 0 & 0\end{array}$

An average line contains six words.

All remittances by Post Office Orders must be made payable to the sibility will be asceptel for any such renittance not so safeguarded. Advertisements should be delivered, addressed to the Manager, 429 Strand, London. W.C.2, not later than the first post on Tuesday morning
preceding publication, and, if not paid for at the time, should be preceding publication, and,

Norg.-It is against the rules of the Post Office to receive poste restante 